\title{
10. CRETACEOUS AGGLUTINATED FORAMINIFERA OF THE ATLANTIC OCEAN OFF WEST AFRICA (LEG 41, DEEP SEA DRILLING PROJECT)
}

\author{
Valery A. Krasheninnikov, Geological Institute of the USSR Academy of Sciences, Moscow, USSR \\ and \\ Uwe Pflaumann, Geologisch-Paleontologisches Institut der Universitat, Kiel, Germany (FRG)
}

\begin{abstract}
Stratigraphic distribution of agglutinated foraminifers in Cretaceous deposits off West Africa is discussed. Aptian-Albian calcareous clays and siltstones of the Morocco Basin (Site 370) are characterized by an assemblage with Plectorecurvoides rotundus and $P$. alternans; agglutinated foraminifers are accompanied by calcareous benthic and planktonic foraminifers and nannoplankton. Upper Cretaceous noncalcareous clays of the Cape Verde Basin and Rise (Sites 367 and 368) contain agglutinated foraminifers as the primary noncalcareous fossil assemblage. An assemblage with Uvigerinammina jankoi and Plectina conversa, which is representative of the Upper Cretaceous, is distinguished along with an assemblage with Rzehakina epigona (epigona, fissistomata, inclusa) and Silicosigmoilina perplexa peculiar to the upper part of the Upper Cretaceous (likely Campanian-Maestrichtian). Brief comments are given on 40 representatives of astrorhizids, saccamminids, hormosinids, ammodiscids, rzehakinids, lituolids, textulariids, trochamminids, and ataxophragmiids.
\end{abstract}

\section{INTRODUCTION}

Frequently, deep-sea sediments lack not only planktonic calcareous organisms but the siliceous plankton as well. Benthic agglutinated foraminifers then comprise the only group of microorganisms. It is such Lower and Upper Cretaceous sediments with agglutinated foraminifers that were recovered from Sites 367, 368, and 370 during Leg 41 of the Deep Sea Drilling Project.

Sometimes, only benthic agglutinated foraminifers are present as an indicator of the age and facies environment, i.e., to be used for the purposes of regional stratigraphy, reproducing the paleoenvironment, and the geological history. The use of agglutinated foraminifers for stratigraphy of oceanic deposits, however, is difficult due to many circumstances. Thus, poor knowledge of morphology, systematics, and specific variability of primitive agglutinated foraminifers results in application of recent specific names for Paleogene and Cretaceous forms. As a consequence, the intervals of distribution of many species are very wide, which lessens their stratigraphic importance (ammodiscids, saccamminids, hormosinids, astrorhizids, etc.). As a rule, the specific variability of many species of agglutinated foraminifers with complicated structures (lituolids, textulariids, trochamminids, ataxophragmiids, rzehakinids, etc.) are known much better, but their stratigraphic distribution has only been generally outlined.

The data from the Deep Sea Drilling Project, as well as the results of studying agglutinated foraminifers from Cretaceous deposits on the continents, testify to a wide geographical distribution of some forms. Thus, Silicosigmoilina perplexa, Rzehakina epigona (with varieties), Plectina conversa, Uvigerinammina jankoi, Dorothia oxycona, Trochammina globigeriniformis, Recurvoides gerochi, Thalmannammina subturbinata, and other species of primitive and more complicated species of agglutinated foraminifers were found in Cretaceous deposits of the oceans and continents. This emphasizes their importance for subdivision and correlation of Lower and Upper Cretaceous sediments. The modest aim of this paper is to show the distribution peculiarities and emphasize the necessity of future study of agglutinated foraminifers from deep-water Cretaceous deposits off West Africa.

\section{STRATIGRAPHIC DISTRIBUTION OF AGGLUTINATED FORAMINIFERS IN CRETACEOUS DEPOSITS OFF THE WEST AFRICAN COAST}

Deep-water sediments of the Lower and Upper Cretaceous with agglutinated foraminifers occur at Site 367 (water depth $4748 \mathrm{~m}$ ) in the Cape Verde Basin, Site 368 (water depth $3367 \mathrm{~m}$ ), on the Cape Verde Rise, and Hole 370 (depth $4216 \mathrm{~m}$ ) in the Morocco Basin (Figure 1).

In the Cape Verde Basin (Hole 367) the Neocomian limestones are characterized by a relatively poor assemblage of agglutinated foraminifers with Dorothia praehauteriviana, that are accompanied by various calcareous benthonic foraminifers and nannoplankton. Aptian-Turonian (?) black shales are generally poor in benthonic microfauna (numerous 
planktonic foraminifers and nannoplankton being available). Only in some interbeds there occur rare representatives of Rhabdammina, Dendrophyra, Ammodiscus, Glomospira, Haplophragmoides, Recurvoides, Trochammina, Bolivinopsis.

Turonian (?) black shales are separated from graygreenish clays with radiolarians of the upper Paleocenelower Eocene (the Bekoma bidartensis Zone) by an interval of about 220 meters, in which only two cores (Cores 15 and 16) were taken. The deposits in this interval are presented by noncalcareous multicolored silty clays: gray-greenish, green, and reddish-brown clays with an alternate amount of silty and arenaceous material. Thin interbeds of black shales appear to evidence of a gradual transition towards a thick member of black shales of the Aptian-Turonian (?).

Variegated clays are characterized by various agglutinated foraminifers: Silicosigmoilina perplexa, Trochamminoides coronatus, Dorothia oxycona, Uvigerinammina jankoi, Ammodiscus cretaceus, Glomospira gordialis, G. corona, Hormosina ovulum, Saccammina placenta, S. complanata, Kalamopsis grzybowskii, Dendrophyra excelsa, Psammosiphonella anglesiaensis, Plectina conversa, and other species of Psammosiphonella, Hyperammina, Ammodiscus, Haplophragmoides, Paratrochamminoides, Spiroplectammina, Recurvoides, and Reophax. The assemblage of foraminifers testifies to the Upper Cretaceous age of the clays, though a number of species is known from Lower Cretaceous and Paleogene deposits. There are practically no representatives of other groups of microorganisms in variegated clays, except for the rare nannoplankton of the Coniacian-Maestrichtian age established in Core 16.

On the Cape Verde Rise the drilling of Hole 368 was over in black shales with poor planktonic foraminifers and Cenomanian-Turonian nannoplankton. The assemblage of agglutinated foraminifers consists of sporadic Uvigerinammina jankoi, Thalmannammina subturbinata, Saccammina complanata, Haplophragmoides sp., Hyperammina sp. sp., Trochammina globigeriniformis, $T$. sp., Kalamopsis grzybowskii, Ammodiscus cretaceus, Plectina conversa, Psammosiphonella anglesiaensis, Rhizammina sp., Trochamminoides coronatus, Glomospira gordialis, Recurvoides sp. (Cores 58-62), these confirming the Upper Cretaceous age of the sediments.

Black shales are replaced by a pile of alternating reddish-brown, green, and gray-green noncalcareous clays (Cores 55-57); their thickness is about 80 meters. These deposits are characterized by scarce agglutinated foraminifers of the Upper Cretaceous-Plectina conversa, Recurvoides gerochi, Glomospira corona, Glomospirella gaultina, Reophax pilulifer, Saccammina placenta, $S$. complanata, Ammodiscus cretaceus, Rhizammina algaeformis, Psammosiphonella cylindrica, Trochammina sp., and Trochamminoides proteus. Other organic remains are absent here.

The variegated clays are overlain by monotonous noncarbonated dark and pale green clays and silty clays, about 140 meters thick (Cores 50-54). Agglutinated foraminifers are recognized here more frequently. Their specific composition is similar to the just given one, but they are almost always accompanied by Rzehakina epigona epigona, $R$. epigona inclusa, $R$. epigona fissistomata, and Silicosigmoilina perplexa. The Rzehakina epigona s.l. is typical for deposits of the upper part of the Upper Cretaceous (CampanianMaestrichtian) to Paleocene. Since sparse Cretaceous radiolarian assemblages were found in Core 368-52, there are reasons to attribute the member of clays with Rzehakina epigona s.l. to the later part of the Upper Cretaceous. This assumption, unfortunately, cannot be reliably proved, as there are no other groups of fossil microorganisms.

Layers with Rzehakina epigona (Upper Cretaceous, Core 368-50) and those with an Eocene assemblage of spores and pollen (Core 368-41) are divided by a member of analogous noncarbonate gray-greenish clays, practically devoid of organic remains. The thickness is over 100 meters (Cores 368-42 to 368-49). Primitive Rhizammina, Ammodiscus, Glomospira, and Hyperammina are very rare. The age of these sediments can be placed within the Upper Cretaceous (uppermost part) to Paleocene.

In the Morocco Basin (Site 370) the Lower Cretaceous sediments are composed of monotonous calcareous clays, silty and sandy clays, nanno clays and greenish-gray siltstones. Their thickness reaches 513 meters. Agglutinated foraminifers in these deposits are accompanied by calcareous benthonic and planktonic foraminifers and nannoplankton.

Valaginian and Hauterivian deposits contain the Dorothia praehauteriviana assemblage including both the agglutinated and calcareous benthonic foraminifers (see I. Seibold and Kuznetsova, this volume).

Late Hauterivian, Barremian, and lower Aptian deposits contain few agglutinated foraminifers.

Agglutinated foraminifers are relatively diverse in calcareous clays on the late Aptian-Albian (including the Rotalipora apenninica Zone transitional to the Cenomanian), where they are accompanied by abundant planktonic and calcareous benthic foraminifers, nannoplankton, and calcisphaerulids (Cores 370-20 to 370-31). Their assemblage consists of Hyperammina gaultina, Rhizammina indivisa, Psammosiphonella sp., Kalamopsis grzybowskii, Saccammina placenta, Hormosina ovulum, Psammosphaera fusca, Glomospira charoides, Ammodiscus rugosus, A. cretaceus, Trochamminoides sp., Reophax sp., Spiroplectammina gandolfii, $S$. sp., Textularia sp., Dorothia oxycona, Trochammina globigeriniformis, Recurvoides aff. pseudosymmetricus, $R$. imperfectus, Plectorecurvoides alternans, and $P$. rotundus.

Late Albian-early Cenomanian clays at Site 370 are unconformably overlain by Paleocene deposits.

Thus, the Cretaceous deposits penetrated at Sites 367,368 , and 370 are characterized by four assemblages of agglutinated foraminifers: assemblage with Dorothia praehauteriviana, developed in Neocomian (Valanginian-Hauterivian) sediments (See Seibold and Kuznetsova, this volume); assemblage with Plectorecurvoides alternans and $P$. rotundus (late Aptian-Albian); assemblage with Uvigerinammina jankoi, Plectina conversa, and other species (Upper 
Cretaceous); assemblage with Rzehakina epigona s.l. and Silicosigmoilina perplexa, tending towards the upper part of the Upper Cretaceous (evidently Campanian-Maestrichtian). We hope that a detailed study of agglutinated foraminifers will result in a much better stratification of Cretaceous deposits.

Lower Cretaceous agglutinated foraminifers are observed in calcareous clays; they are accompanied by diverse calcareous benthic and planktonic foraminifers and nannoplankton. Upper Cretaceous agglutinated foraminifers occur in noncalcareous argilaceous sediments, where representatives of other groups of microorganisms are practically absent. By the generic and specific composition these assemblages of agglutinated foraminifers are very similar to those from synchronous flysch and flysch-like sediments of the Alps, Carpathians, and Caucasus. On the whole, physical-chemical conditions of accumulation of Upper Cretaceous sediments of the Atlantic Ocean and Alpine geosynclines were certainly rather different, which testifies to significant differences of oceanic and flysch sediments of these two areas. However, there were some general ecological factors that caused the origination of similar assemblages of agglutinated foraminifers. The establishing of these factors is a subject of further studies.

\section{SYSTEMATIC DESCRIPTION}

In this part some comments on certain species of agglutinated foraminifers in Cretaceous deposits recovered from Sites 367, 368, and 370 are given. The definition of some species is conventional, as a correct identification should be carried out by means of thin sections of the wall or the initial part of a test. Some species are described with an open nomenclature or trivial specific names.

The origmals of the species are kept in the Micropaleontological laboratory of the Geological Institute of the USSR Academy of Sciences in Moscow. The photographs of foraminifers were made by A.I. Nikitin and retouched by A.N. Makarevich, to whom the authors express their sincere gratitude.

\section{Family ASTRORHIZIDAE Brady, 1881}

Genus PSAMMOSIPHONELLA Avnimelech, 1952

Psammosiphonella anglesiaensis (Crespin)

(Plate 1, Figures 3, 4)

1950. Bathysiphon anglesiaensis Crespin, p. 71, pl. 10, fig. 1.

Elongated (up to $1.5 \mathrm{~mm}$ ) and broad (up to $0.75 \mathrm{~mm}$ ) tubular tests, without constrictions, sometimes slightly curved (Figure 4). Under magnification $50 \times$ a regular fine granularity of the wall with separate larger inclusions is visible.

The Upper Cretaceous of the Cape Verde Basin and Cape Verde Rise (Sites 367, 368). It was described originally from the middle Eocene of Australia.

\section{Psammosiphonella cylindrica (Glaessner)}

(Plate 1, Figure 12)

1937. Rhabdammina cylindrica Glaessner, p. 354 , pl. 1 , fig. 1.

The test is tubular, elongated (up to $1.25 \mathrm{~mm}$ ), of moderate width (up to $0.32 \mathrm{~mm}$ ), straight, without constrictions. Under magnification $75 \times$ the wall looks coarse grained, the grains being of an irregular shape and various size.

The Upper Cretaceous of the Cape Verde Rise (Site 368). The species was defined for the first time from the Paleocene of the USSR (North Caucasus).

\section{Psammosiphonella alexanderi (Cushman)}

(Plate 1, Figures 1, 2)

1933. Bathysiphon alexanderi Cushman, p. 49, pl. 5, fig. 1 .
The test is tubular, straight, elongated (up to $1.4 \mathrm{~mm}$ ), thin (its width not exceeding $0.25 \mathrm{~mm}$ ), without constrictions. Under magnification $75 \times$ the microstructure of the wall appears as a background of fine granularity upon which there are numerous coarser grains of irregular shape.

The Upper Cretaceous of the Cape Verde Basin and Rise (Sites $367,368)$. It was originally defined from the Upper Cretaceous of Texas, USA.

\section{Genus RHIZAMMINA Brady, 1879}

\section{Rhizammina algaeformis Brady} (Plate 1, Figure 5)

1879. Rhizammina algaeformis Brady, p. 20, pl. 4, fig. 16, 17.

The test is tubular, long (up to $1.4 \mathrm{~mm})$, thin $(0.12 \mathrm{~mm})$, curved at various sides, with obscure constrictions. The microstructure of the wall is characterized by very fine and even grains (under magnification $75 \times$ ).

The Upper Cretaceous of the Cape Verde Rise (Site 368). The species was described for the first time from the recent sediments.

\section{Genus DENDROPHRYA Wright, 1861}

\section{Dendrophrya excelsa Grzybowski}

(Plate 1, Figures 6, 7)

1897. Dendrophrya excelsa Grzybowski, p. 272, pl. 10, fig. 1-4.

The test is a thin straight tube (length up to $1.13 \mathrm{~mm}$, width up to $0.17 \mathrm{~mm}$ ) with bifurcation, two rays (tubes) being arranged symmetrically relative to the axis of the previous tube. Under magnification $75 \times$ the microstructure of the wall is extremely fine grained.

The Upper Cretaceous of the Cape Verde Basin (Site 367). The species was originally defined from the Paleogene of Poland, later it was recognized in the Upper Cretaceous flysch of the Alps and Carpathians (Hanzlikova, 1973).

\section{Genus HYPERAMMINA Brady, 1878}

\section{Hyperammina gaultina ten Dam}

(Plate 1, Figures 10, 11)

1950. Hyperammina gaultina ten Dam, p. 5, pl. 1, fig. 2.

The test is tubular, elongated (up to $1.38 \mathrm{~mm}$ ), divided by constrictions into segments. The latter are wider in the proximal part and narrower in the distal (apertural) part. The maximum width is up to $0.38 \mathrm{~mm}$. Not over three segments were observed in one test. Under magnification $75 \times$ the wall is fine grained.

The Upper Cretaceous of the Cape Verde Basin (Site 367). The species was described for the first time from the Albian of the Netherlands.

\section{Hyperammina friabilis Brady}

(Plate 1, Figure 8)

1884. Hyperammina friabilis Brady, p. 258, pl. 23, fig. 1, 2, 3, 5, 6 .

The test is tubular, long (up to $2 \mathrm{~mm}$ ), divided by vague constrictions into segments. The length of the latter usually exceeds their width. The segments are either of the cylindrical shape, or suboval (widest in their middle part). Under magnification $75 \times$ the wall is regularly fine grained and smooth.

The Upper Cretaceous of the Cape Verde Basin and Rise (Sites 367 and 368). This species is attributed to the recent $H$. friabilis conventionally.

\section{Hyperammina subnodosa Brady}

(Plate 1, Figure 9)

1884. Hyperammina subnodosa Brady, p. 159, pl. 23, fig. 11-14.

The test is tubular, elongated (up to $1.5 \mathrm{~mm}$ ), usually slightly curved, divided into segments by constrictions. The segments are of the subsquare shape, as the width and length of a segment are approximately equal. Under magnification $75 \times$ the wall looks fine grained with rare larger grains.

The Upper Cretaceous of the Cape Verde Basin and Rise (Sites 367 and 368 ). The species is attributed to the recent $H$. subnodosa conditionally. 
Family SACCAMMINIDAE Brady, 1884

Genus SACCAMMINA Sars, in Carpenter, 1869

Saccammina complanata (Franke)

(Plate 1, Figure 14)

1912. Pelosina complanata Franke, p. 107, pl. 3, fig. 1.

The test is spherical or subspherical, with a rounded aperture arranged on a short neck; under magnification $75 \times$ the wall is regularly fine grained, almost smooth. Diameter-up to $0.5 \mathrm{~mm}$.

The Upper Cretaceous of the Cape Verde Basin (Site 367).

\section{Saccammina placenta (Grzybowski)}

(Plate 1, Figure 16)

1898. Reophax placenta Grzybowski, p. 276, pl. 10, fig. 9-10.

The test is broadly oval, slightly elongated towards the aperture, that is arranged terminally and is rimmed by a thin lip. Under magnification $75 \times$ the wall is fine grained, almost smooth. The largest diameter is up to $0.48 \mathrm{~mm}$.

The Lower Cretaceous (Aptian-Albian) of the Morocco Basin (Site 370); Upper Cretaceous of the Cape Verde Basin and Rise (Sites 367 and 368).

\section{Genus PSAMMOSPHAERA Schulze, 1875 \\ Psammosphaera fusca Schulze \\ (Plate 1, Figure 15)}

1875. Psammosphaera fusca Schulze, p. 113, pl. 2, fig. 3a-f.

The test is almost spherical, slightly elongated towards the aperture that has the rounded shape, arranged terminally and rimmed by a thin lip. Under magnification $75 \times$ the wall is coarse grained; on the background of small grains there are numerous coarser grains of irregular shape. The largest diameter is up to $0.53 \mathrm{~mm}$.

The Lower Cretaceous (Aptian-Albian) of the Morocco Basin (Site 370).

\section{Family Hormosinidae Haeckel, 1894}

Genus HORMOSINA Brady, 1879

\author{
Hormosina ovulum (Grzybowski)
}

(Plate 1, Figures 17, 18)

1896. Reophax ovulum Grzybowski, p. 276, pl. 8, fig. 19-21.

The test is subspherical, drop-like, widest at the base and narrowing towards the aperture. The aperture is arranged terminally, rounded, on a low eminence (Figure 17) or a distinct apertural neck (Figure 18). The wall under magnification $75 \times$ is extremely finegrained (grains are sometimes indiscernible, Figure 17), smooth and lustrous. The largest diameter is $0.43 \mathrm{~mm}$.

At the base of the chamber there is the second opening and the apertural neck that appeared to connect the adjacent chambers. However, multichambered tests have not been observed in our material. It is not excluded that the species can be assigned to the monochambered genus Pelosina.

The Upper Cretaceous of the Cape Verde Basin and Rise (Sites 367 and 368 ).

\section{Genus KALAMOPSIS De Folin, 1883}

\section{Kalamopsis grzybowskii (Dylazanka)}

$$
\text { (Plate 1, Figure 13) }
$$

1923. Hyperammina grzybowskii Dylazanka, p. 65; Geroch, 1960, p. $39,89,121$, pl. 1 , fig. 22,23 , pl. 10 , fig. 7 .

The test is elongated, bottle-like shaped, frequently almost tubular, with slightly narrowing ends, straight or slightly curved; the aperture has the shape of a rounded opening. The wall is very thin, írequently deformed, smooth, lustrous, and polished. Its microstructure is fine grained; separate grains are almost not seen under magnification $75 \times$. The length - up to $0.57 \mathrm{~mm}$; width—up to 0.15 $\mathrm{mm}$.

Our material contains only broken chambers and no multichambered complete tests.

The Lower Cretaceous (Aptian-Albian) of the Morocco Basin (Site 370), Upper Cretaceous of the Cape Verde Basin and Rise (Sites 367 and 368).
Genus REOPHAX Montfort, 1808

\section{Reophax pilulifer Brady}

(Plate 2, Figure 1)

1884. Reophax pilulifer Brady, p. 292, pl. 30 , fig. $18-20$.

The test consists of 3-4 chambers arranged in the linear direction in one row and strongly flattened in the direction of growth. The chambers are separated by deep septal sutures. The aperture is terminal, rounded, and is arranged on the cone-shaped apertural neck connecting the adjacent chambers. Under magnification $75-100 \times$ the wall is fine grained. The length of the test is up to $0.5 \mathrm{~mm}$ and width up to $0.38 \mathrm{~mm}$.

The Upper Cretaceous of the Cape Verde Rise (Site 368). The species was defined for the first time from the recent deposits and later recognized in Upper Cretaceous and Paleogene sediments in many countries.

\section{Family AMMODISCIDAE Reuss, 1862}

Genus GLOMOSPIRA Rzehak, 1885

Glomospira corona Cushman and Jarvis

(Plate 2, Figures 2a, b)

1928. Glomospira charoides (Jones and Parker) var. corona Cushman and Jarvis, p. 89, pl. 12, fig. 9-11.

The test is high trochospiral, cylindrical with a vault-like initial part. It is composed of 5-7 whorls of the tubular nonsegmented chamber. The wall is siliceous, smooth, lustrous, homogeneous, extremely fine grained. Under magnification $100 \times$ grains of the wall are not visible. The height of the test is up to $0.30 \mathrm{~mm}$ and width up to $0.25 \mathrm{~mm}$.

The Upper Cretaceous of the Cape Verde Basin and Rise (Sites 367 and 368$)$.

\section{Glomospira charoides (Jones and Parker)} (Plate 2, Figures 3a, b)

1860. Trochammina squamata var. charoides Jones and Parker, p. 304; Glomospira charoides (Jones and Parker) Cushman, 1918, p. 100 , pl. 36 , fig. 10-15.

The test is low trochospiral, irregularly spherical or irregularly lenticular, consisting of 4-7 whorls of a tubular chamber. The coiling of the earlier whorls is relatively regular; the later whorls coil in some planes. The wall is siliceous, homogeneous; under magnification $100 \times$ no grains were practically seen. Height is up to $0.33 \mathrm{~mm}$ and width up to $0.43 \mathrm{~mm}$.

The Lower Cretaceous of the Morocco Basin (Site 370); the Upper Cretaceous of the Cape Verde Basin and Rise (Sites 367 and 368).

\section{Glomospira gordialis (Jones and Parker)}

$$
\text { (Plate 2, Figures } 4 a, b \text { ) }
$$

1860. Trochammina squamata var. gordialis Jones and Parker, p. 304; Glomospira gordialis (Jones and Parker) Cushman, 1918, p. 100, pl. 36 , fig. 7-9.

The test, is of an irregular shape as the initial whorls form a relatively regular descending low spiral, whereas the later whorls are coiling chaotically, under different inclinations. The wall is fine grained (under magnification $75 \times$ ), almost smooth. The height is up to $0.38 \mathrm{~mm}$ and width is up to $0.88 \mathrm{~mm}$.

The Upper Cretaceous of the Cape Verde Basin and Rise (Sites 367 and 368 ).

\section{Genus GLOMOSPIRELLA Plummer, 1945}

\section{Glomospirella gaultina (Berthelin)}

(Plate 2, Figure 5)

1880. Ammodiscus gaultinus Berthelin, p. 19, pl. 1, fig. 3 .

The test is flat, discoidal. The initial part consists of some whorls of a tubular chamber forming a glomospira-like low trochoidal coil. The later 1-2 whorls coil in one plane, planispirally. The wall is siliceous and smooth. Under magnification $75 \times$ the grains of the wall are practically not visible. Diameter is up to $0.63 \mathrm{~mm}$.

The Upper Cretaceous of the Cape Verde Rise (Site 368). 
Genus AMMODISCUS Reuss, 1862

\section{Ammodiscus cretaceus rugosus Schijfsma}

(Plate 2, Figure 6)

1946. Ammodiscus cretaceus (Reuss) var. rugosa Schijfsma, p. 28 , pl. 6, fig. 2 .

The flat discoidal test is formed by 5-6 whorls of a tubular chamber, slightly involute, sometimes with vague constrictions. A characteristic feature of the subspecies is fine or even middle granularity of the wall (under magnification $75 \times$ ), its surface being uneven. Diameter is up to $0.80 \mathrm{~mm}$.

The Lower Cretaceous (Aptian-Albian) of the Morocco Basin (Site 370 ). The species was originally described from the Upper Cretaceous of the Netherlands.

\section{Ammodiscus cretaceus cretaceus (Reuss)}

(Plate 2, Figure 7)

1845. Operculina cretacea Reuss, p. 35 , pl. 13, fig. 64-65.

The variety $A$. cretaceus cretaceus is similar to $A$. cretaceus rugosus by the general shape of the test and slightly involute whorls, abruptly differing in a siliceous homogeneous wall (under magnification $75 \times$ few grains are visible). Diameter is up to 0.73 $\mathrm{mm}$.

The Lower Cretaceous (Aptian-Albian) of the Morocco Basin (Site 370); the Upper Cretaceous of the Cape Verde Basin and Rise (Sites 367 and 368)

\section{Ammodiscus glabratus Cushman and Jarvis}

(Plate 2, Figures 8, 9)

1932. Ammodiscus glabratus Cushman and Jarvis, p. 86, pl. 12 , fig. 6 .

A strongly compressed discoidal test formed by numerous (up to 9) involute whorls of a tubular chamber. The wall is siliceous, smooth, and homogeneous; under magnification $75 \times$ no grains of the wall can be observed. Diameter is up to $0.75 \mathrm{~mm}$.

The Upper Cretaceous of the Cape Verde Basin and Rise (Sites 367 and 368). It was described for the first time from the Upper Cretaceous of the USA.

\section{Ammodiscus pennyi Cushman and Jarvis}

(Plate 2, Figures 10,11)

1928. Ammodiscus pennyi Cushman and Jarvis, p. 37 , pl. 12 ,

fig. 4,5 .

The test is strongly compressed, thin, with an irregularly oval outline, formed by 2-3 evolute whorls of a tubular chamber. Under magnification $50-75 \times$ the wall is fine grained, with an uneven surface. Diameter is up to $1 \mathrm{~mm}$.

The Upper Cretaceous of the Cape Verde Basin and Rise (Sites 367 and 368). It was described for the first time from the Upper Cretaceous of the USA.

Family RZEHAKINIDAE Cushman, 1933

Genus SILICOSIGMOILINA Cushman and Church, 1929

Silicosigmoilina perplexa Israelsky

(Plate 2, Figures 12a, b)

1951. Silicosigmoilina (Bramletteia) perplexa Israelsky, p. 11, pl. 2,

fig. $22-25$, pl. 10, fig. 21.

The test is ovoid, almost triangular in the cross-section, formed by a series of chambers with the sigmoidal arrangement, three chambers being observed on each side. The rounded apertural opening is provided with a tooth-like projection. The wall is characterized by fine grains (under magnification $75 \times$ ), almost smooth. The length is up to $0.63 \mathrm{~mm}$ and width is up to $0.30 \mathrm{~mm}$.

The Upper Cretaceous of the Cape Verde Basin and Rise (Sites 367 and 368). The species was described for the first time from the Paleogene of California (Lodo Formation), but later it was observed in Upper Cretaceous deposistd of many countries.

Genus RZEHAKINA Cushman, 1927

Rzehakina epigona epigona (Rzehak)

(Plate 3, Figures 5a, b, 11)

1895. Silicina epigona Rzehak, p. 214, pl. 6, fig. 1.
The test is ovoid and strongly compressed at the lateral sides, with the planispiral spiroloculina-type arrangement of involute chambers. The central parts of the lateral sides are concave. The peripheral margin is narrow and sharpened. The aperture has the shape of a narrow oval opening. The wall is siliceous, homogeneous, smooth and sometimes semitransparent; under magnification $75 \times$ the grains of the wall are almost not seen. Diameter is up to $1 \mathrm{~mm}$, and thickness of the test is up to $0.27 \mathrm{~mm}$.

The upper part of the Upper Cretaceous of the Cape Verde Rise (Site 368).

\section{Rzehakina epigona fissistomata (Grzybowski)}

(Plate 3, Figures 1, 2, 3)

1901. Spiroloculina fissistomata Grzybowski; 1974, Rzehakina epigona fissistomata (Grzybowski), Hiltermann, p. 43, pl. 5, fig. 3, 4, 12, 27,34, pl. 6 , fig. $11,16,30$.

This variety differs from $R$. epigona epigona in having weakly involute chambers (consequently the chambers of the early whorls are seen) and a very thin flattened test. The wall is siliceous, homogeneous, smooth, very thin, semitransparent (an early chamber can be seen through the wall of a later chamber). The length is up to $0.87 \mathrm{~mm}$, width is up to $0.50 \mathrm{~mm}$, and thickness is up to $0.15 \mathrm{~mm}$.

The upper part of the Upper Cretaceous of the Cape Verde Rise (Site 368).

\section{Rzehakina epigona inclusa (Grzybowski)}

(Plate 3, Figures 6a, b)

1901. Spiroloculina inclusa Grzybowski; 1974, Rzehakina epigona inclusa (Grzybowski), Hiltermann, p. 43, pl. 5, fig. 8, 29-33, 37 . 41 ; pl. 6, fig. 7, 18-26.

This variety resembles $R$. epigona epigona by its involute chambers, but the test is thicker, with a rounded peripheral margin, rounded aperture; the lateral sides are flat, but not concave. The wall is very fine grained, almost homogeneous, smooth. The length is up to $0.72 \mathrm{~mm}$, width is up to $0.42 \mathrm{~mm}$, and thickness is up to $0.30 \mathrm{~mm}$.

The upper part of the Upper Cretaceous of the Cape Verde Rise (Site 368).

These three varieties of Rzehakina epigona are widely distributed geographically: Alaska, California, Texas, Mexico, Trinidad, Ecuador, Venezuela, many countries of Europe and north Africa, Japan, the Kamchatka peninsula, and New Zealand. They are associated with late Upper Cretaceous (Campanian-Maestrichtian) to Paleocene deposits. The data on the geographical and stratigraphical distribution of $R$. epigona s.l. are summarized in the papers by Serova $(1966,1969)$ and Hiltermann (1974). These varieties which are found in deep-water Upper Cretaceous sediments of the Atlantic Ocean, confirm the stratigraphic importance of rzehakins.

\section{Family ATAXOPHRAGMIIDAE Schwager, 1877}

\section{Genus PLECTINA Marsson, 1878}

\section{Plectina conversa (Grzybowski)}

(Plate 3, Figures 4a, b)

1901. Gaudryina conversa Grzybowski, p. 285, pl. 7, fig. 15, 16. The test is elongated, with an initial trochospiral part (4-5 indistinct chambers in the whorl) and a later biserial part (6-7 rows of chambers), compressed laterally and sometimes twisted. The aperture is areal, oval. Under magnification $75 \times$ the wall is fine grained, with a rough surface. Length is up to $0.95 \mathrm{~mm}$ and width is up to $0.20 \mathrm{~mm}$.

The Upper Cretaceous sediments of the Cape Verde Basin and Rise (Sites 367 and 368). This species is widely developed in the Upper Cretaceous of the continents and has been met in synchronous sediments of the Indian Ocean (Krasheninnikov, 1974).

\section{Genus UVIGERINAMMINA Majzon, 1943}

Uvigerinammina jankoi Majzon

(Plate 3, Figures 12a, b, 13a, b)

1943. Uvigerinammina jankoi Majzon, p. 158, pl. II, fig. 15

The test is highly trochoid, broadly fusiform, with three chambers per whorl. The last three chambers occupy more than half of the test. The aperture is oval or rounded opening situated terminally on a short neck, with a narrow lip. Under magnification $100 \times$ the wall is clearly granular with a rough surface. Length is up to $0.38 \mathrm{~mm}$ and width is up to $0.25 \mathrm{~mm}$. 
The Upper Cretaceous of the Cape Verde Basin and Rise (Sites 367 and 368). This species was originally described from the Upper Cretaceous of Hungary and then was found in many countries of Europe, as well as in Indian Ocean sediments.

\section{Genus DOROTHIA Plummer, 1931}

Dorothia oxycona (Reuss)

(Plate 4, Figures 1a, b, 2a, b)

1860. Gaudryina oxycona Reuss, p. 229, pl. 12, fig. 3a, b, c.

The test is conical, with a slightly concave apertural face, 4-5 chambers per whorl occur in the initial part. The test is biserial on later stages, with indistinct septal sutures and a slit-like aperture at the inner margin of the last chamber. The wall is siliceous, homogeneous, smooth, and sometimes fine grained under magnification 75 $100 \times$. Length is up to $0.62 \mathrm{~mm}$ and width is up to $0.35 \mathrm{~mm}$.

The Lower Cretaceous (Aptian-Albian) of the Morocco Basin (Site 370); Upper Cretaceous of the Cape Verde Basin and Rise (Sites 367 and 368 ).

Family LITUOLIDAE de Blainville, 1825

Genus TROCHAMMINOIDES Cushman, 1910

Trochamminoides proteus (Karrer)

(Plate 4, Figures 3a, b)

1866. Trochammina proteus Karrer, p. 494, pl. 1, fig. 8 .

The test is oval, thick, planispiral, with five elongated chambers in the last whorl; arrangement of the earlier chambers is unclear, evidently irregular. The wall is fine grained and rough. Diameter (largest) is $1.30 \mathrm{~mm}$ and width is up to $0.50 \mathrm{~mm}$.

The Upper Cretaceous of the Cape Verde Rise (Site 368).

Trochamminoides coronatus (Brady)

(Plate 4, Figures 4a, b)

1879. Trochammina coronata Brady, p. 39 , pl. 5, fig. 15.

This species is distinguished from $T$. proteus by a more compressed test with more numerous chambers (6-7 in the last whorl). The wall is fine grained and its surface is rough. Diameter is up to $0.87 \mathrm{~mm}$ and width is up to $0.27 \mathrm{~mm}$.

The Upper Cretaceous of the Cape Verde Basin (Site 367). The attribution of this species to the recent $T$. coronatus is conditional.

Genus PARATROCHAMMINOIDES Soliman, 1972

Paratrochamminoides sp. sp.

(Plate 4, Figures 6a, b, 7)

Species of the genus under consideration differ from repiesentatives of Trochamminoides in having irregular arrangement of chambers at all stages of development. They are relatively rare in the Upper Cretaceous sediments of the Cape Verde Basin and Rise (Sites 367 and 368 ). These species are characterized by a thin fine grained wall, very often damaged, creating difficulties in determination of their precise specific names.

\section{Genus RECURVOIDES Earland, 1934}

\section{Recurvoides imperfectus Hanzlikova}

(Plate 4, Figures 9a, b, c)

1953. Recurvoides imperfectus Hanzlikova, p. 38, pl. 9, fig. 1.

The test is broadly oval, almost spherical, with streptospiral coiling. The last whorl is formed by $10-12$ chambers visible on one side of the test; there are only 6-7 chambers on the opposite lateral side. The aperture is areal, slit-like. Under magnification $75 \times$ the wall is fine grained. Diameter is up to $0.50 \mathrm{~mm}$ and width is up to 0.38 $\mathrm{mm}$.

The Lower Cretaceous (Aptian-Albian) of the Morocco Basin (Site 370). This species was mentioned from Lower and Upper Cretaceous and Paleogene sediments of Europe.

\section{Recurvoides gerochi Pflaumann \\ (Plate 5, Figures 2a, b, c)}

1964. Recurvoides gerochi Pflaumann, p. 102, pl. 14, fig. 1a-d.

The test is broadly oval with very irregular streptospiral coiling. This explains the different outlook of lateral sides. The last whorl contains up to 10-11 chambers. The aperture is areal and oval. Under magnification $75 \times$ the wall is medium grained or almost coarse grained. Diameter is up to $0.70 \mathrm{~mm}$, and width up to $0.37 \mathrm{~mm}$.

The Upper Cretaceous of the Cape Verde Rise (Site 368).

\section{Recurvoides aff. pseudosymmetricus Krasheninnikov} (Plate 5, Figures 4a, b, c)

This species with an inflated test and very obscure septal sutures which give false symmetry to the test, resembles $R$. pseudosymmetricus from the Upper Cretaceous of the Indian Ocean (Krasheninnikov, 1974). Indeed, the test is characterized by more or less similar lateral sides. The wall is clearly granular. Diameter is up to $0.45 \mathrm{~mm}$ and width is up to $0.35 \mathrm{~mm}$. The precise determination is rather difficult on account of poor preservation and specific variability.

The Lower Cretaceous (Aptian-Albian) of the Morocco Basin (Site 370).

\section{Genus THALMANNAMMINA Pokorny, 1951}

Thalmannammina ef. subturbinata (Grzybowski)

(Plate 5, Figures 5a, b, c)

This species has much in common with $T$. subturbinata from Paleogene and Upper Cretaceous deposits of Europe. Its rare specimens have been found in the Upper Cretaceous of the Cape Verde Rise (Site 368).

\section{Family TEXTULARIIDAE Ehrenberg, 1838}

Genus PLECTORECURVOIDES Noth, 1952

\section{Plectorecurvoides rotundus Krasheninnikov}

1974. Plectorecurvoides rotundus Krasheninnikov, p. 641, pl. 5, fig. $4 a, b, c, 6 c$.

The test is inflated, spherical, and biserial, with planispiral coiling. The rows of chambers are arranged symmetrically and lateral sides are identical. Every row contains 5 chambers with rapid increases in width. The aperture is areal, slit-like, near the base of the apertural face, and close to its junction with an adjacent chamber of the second row. Under magnification $100 \times$ the wall is fine grained and relatively rough. Diameter is up to $0.47 \mathrm{~mm}$ and width is up to $0.42 \mathrm{~mm}$.

The Lower Cretaceous (Aptian-Albian) of the Morocco Basin (Site 370). The species was originally described from the lower part of the Upper Cretaceous of the Indian Ocean (Krasheninnikov, 1974).

\section{Plectorecurvoides alternans Noth \\ (Plate 5, Figures 6a, b, c)}

1952. Plectorecurvoides alternans Noth, p. 117, fig. 1, 2.

The species differs from $P$. rotundus in an oval (less inflated) test, greater number of chambers (usually 7), slower increase of chamber width, and absence of symmetry of lateral sides. The wall is fine grained (under magnification $75 \times$ ). Diameter is up to $0.38 \mathrm{~mm}$, and width is up to $0.30 \mathrm{~mm}$.

The Lower Cretaceous (Aptian-Albian) of the Morocco Basin (Site 370).

\section{Genus SPIROPLECTAMMINA Cushman, 1927}

\section{Spiroplectammina gandolfii Carbonnier}

(Plate 2, Figure 9)

1952. Spiroplectammina gandolfi Carbonnier, p. 112, pl. 5, fig. $2 a, b$.

Rare specimens of this species were found in the Lower Cretaceous (Aptian-Albian) of the Morocco Basin (Site 370). They are identical to $S$. gandolfii orginally described from the Cenomanian deposits of Taza (Morocco).

\section{Family TROCHAMMINIDAE Schwager, 1877}

Genus TROCHAMMINA Parker and Jones, 1859

Trochammina globigeriniformis (Parker and Jones) altiformis
Cushman and Renz
(Plate 4, Figures 8a, b, c) altiformis Cushman and Renz, p. 24, pl. 3, fig. 7-11. 
Specimens from Site 370 display close resemblance with representatives of this worldwide Upper Cretaceous species, but they occurred in the Lower Cretaceous (Aptian-Albian) sediments of the Morocco Basin.

\section{REFERENCES}

Hanzlikova, E., 1973. Foraminifers of the variegated Godula member in Moravia (Cenomanian-Turonian): Sborn. Geol. Ved. Paleontol., Rada P, sv. 15.

Hiltermann, H., 1974. Rzehakina epigona und Unterarten dieser Foraminifere: Paläont. Z., v. 48, N 1/2.
Krasheninnikov, V.A., 1974. Upper Cretaceous benthonic agglutinated Foraminifera, Leg 27 of the Deep Sea Drilling Project. In Veevers, J.J., Heirtzler, J.R., et al., Initial Reports of the Deep Sea Drilling Project, Volume 27: Washington (U.S. Government Printing Office), p. 631-662.

Serova, M. Ya., 1966. On the taxonomic value of certain morphological features of the representatives of Rzehakinidae and its systematic position. (in Russian). Voprosi Mikropaleont., v. 10. 1969. Comparison of characteristics of Rzehakinidae in the Carpathian region and Pacific province: Ann. Soc. Geol. Pologne, v. 39, p. 1-3. 


\section{PLATE 1}

Figures 1,2 Psammosiphonella alexanderi (Cushman).

1. Sample 367-16, CC.

2. Sample $367-16-1,74-76 \mathrm{~cm}, \times 75$, Upper Cretaceous.

Figures 3, $4 \quad$ Psammosiphonella anglesiaensis (Crespin).

3. Sample $367-16-1,74-76 \mathrm{~cm}$.

4. Sample $367-16, C C \times 50$, Upper Cretaceous.

Figure $5 \quad$ Rhizammina algaeformis Brady.

Sample 368-54-2, 78-80, ×75, Upper Cretaceous.

Figures 6,7 Dendrophrya excelsa Grzybowski.

Sample 367-15, CC, $\times 75$, Upper Cretaceous.

Figure $8 \quad$ Hyperammina friabilis Brady.

Sample 367-16, CC, $\times 75$, Upper Cretaceous.

Figure 9 Hyperammina subnodosa Brady.

Sample $367-15$, CC, $\times 75$, Upper Cretaceous.

Figures 10,11 Hyperammina gaultina ten Dam.

Sample 367-16, CC, $\times 75$, Upper Cretaceous.

Figure 12 Psammosiphonella cylindrica (Glaessner).

Sample $368-50-3,63-65 \mathrm{~cm}, \times 75$, Upper Cretaceous.

Figure 13 Kalamopsis grzybowskii (Dylazanka).

Sample 367-16, CC, $\times 75$, Upper Cretaceous.

Figure 14 Saccammina complanata (Franke).

Sample 367-15, CC, $\times 75$, Upper Cretaceous.

Figure 15 Psammosphaera fusca Schulze.

Sample 370-25, CC, $\times 75$, Lower Cretaceous.

Figure 16 Saccammina placenta (Grzybowski).

Sample $367-16-2,44-46 \mathrm{~cm}, \times 75$, Upper

Cretaceous.

Figures 17, 18 Hormosina ovulum ((Grzybowski).

Sample $367-15, \mathrm{CC}, \times 75$, Upper Cretaceous. 
PLATE 1

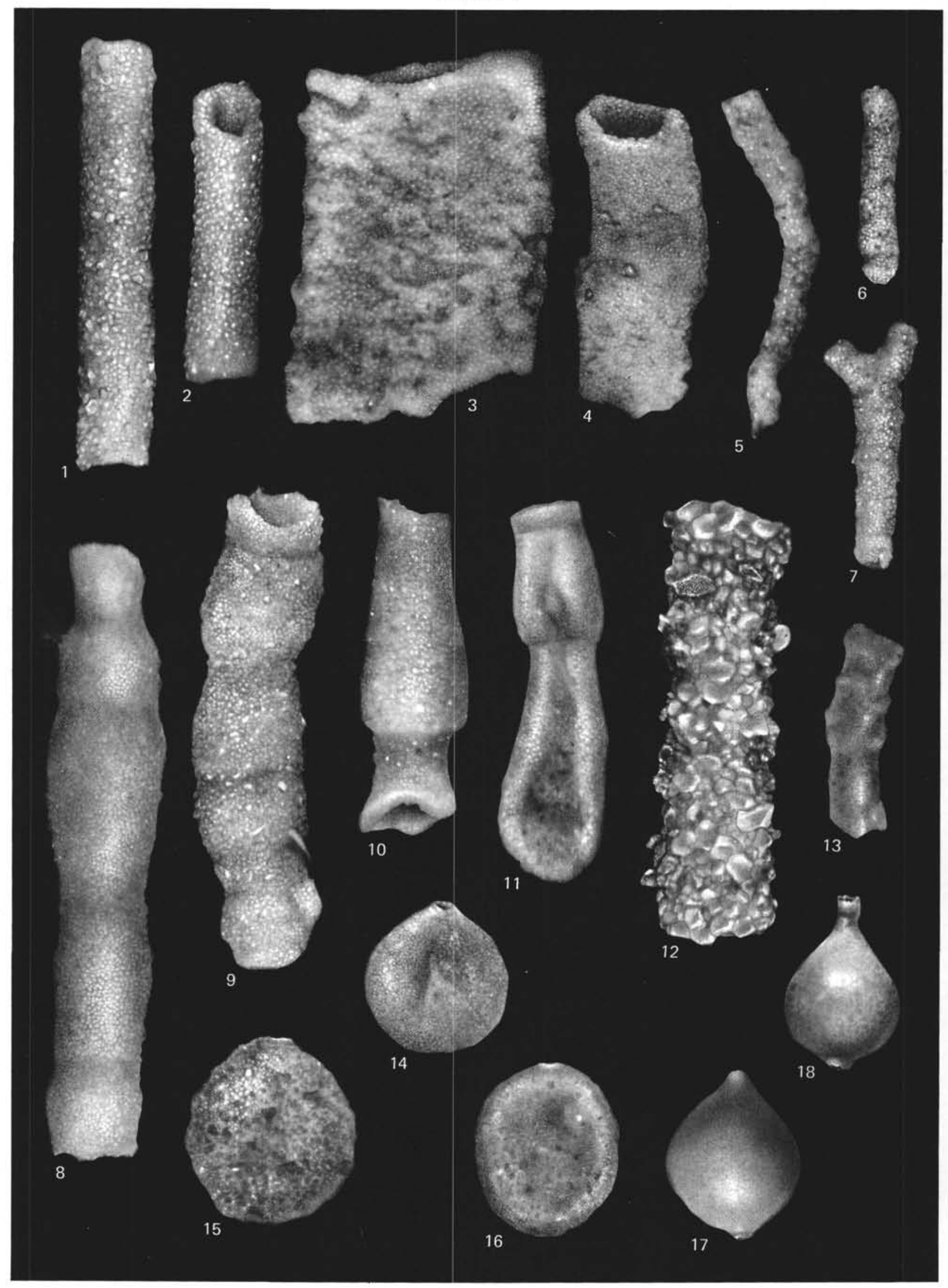




\section{PLATE 2}

Figure $1 \quad$ Reophax pilulifer Brady.

Sample 368-57-1, 53-55 cm, $\times 100$, Upper Cretaceous.

Figures 2a, b Glomospira corona Cushman and Jarvis.

Sample 367-15, CC, $\times 100$, Upper Cretaceous.

Figures 3a, b Glomospira charoides (Jones and Parker).

Sample 370-25, CC, $\times 100$, Lower Cretaceous.

Figures 4a, b Glomospira gordialis (Jones and Parker).

Sample 367-16, CC, $\times 75$, Upper Cretaceous.

Figure 5 Glomospirella gaultina (Berthelin).

Sample 368-50-3, 63-65 cm, ×75, Upper

Cretaceous.

Figure 6 Ammodiscus cretaceus rugosus Schijfsma.

Sample 370-25, CC, $\times 75$, Lower Cretaceous.

Figure 7 Ammodiscus cretaceus cretaceus (Reuss).

Sample 367-15, CC, $\times 75$, Upper Cretaceous.

Figures 8,9 Ammodiscus glabratus Cushman and Jarvis.

Sample 370-24-3, 73-75 cm, $\times 75$, Lower

Cretaceous.

Figures 10,11 Ammodiscus pennyi Cushman and Jarvis.

Sample 367-15, CC.

10. $\times 75$.

11. $\times 50$, Upper Cretaceous.

Figures 12a, b Silicosigmoilina perplexa Israelsky.

Sample 368-53, CC, $\times 75$, Upper Cretaceous. 
PLATE 2

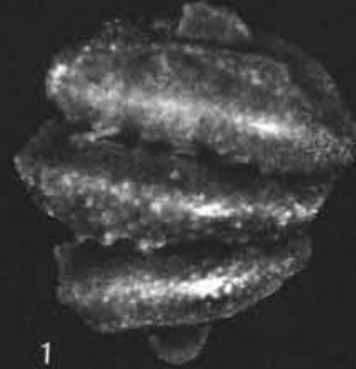

$2 \mathrm{a}$

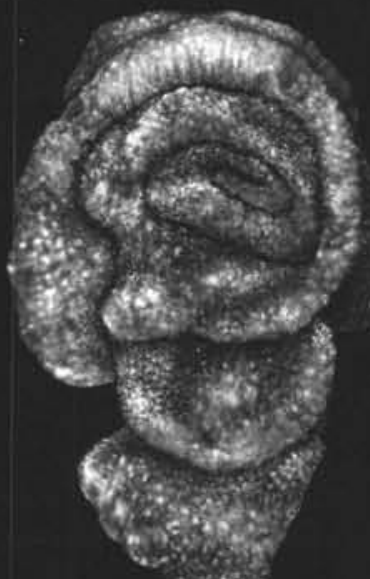

$4 a$
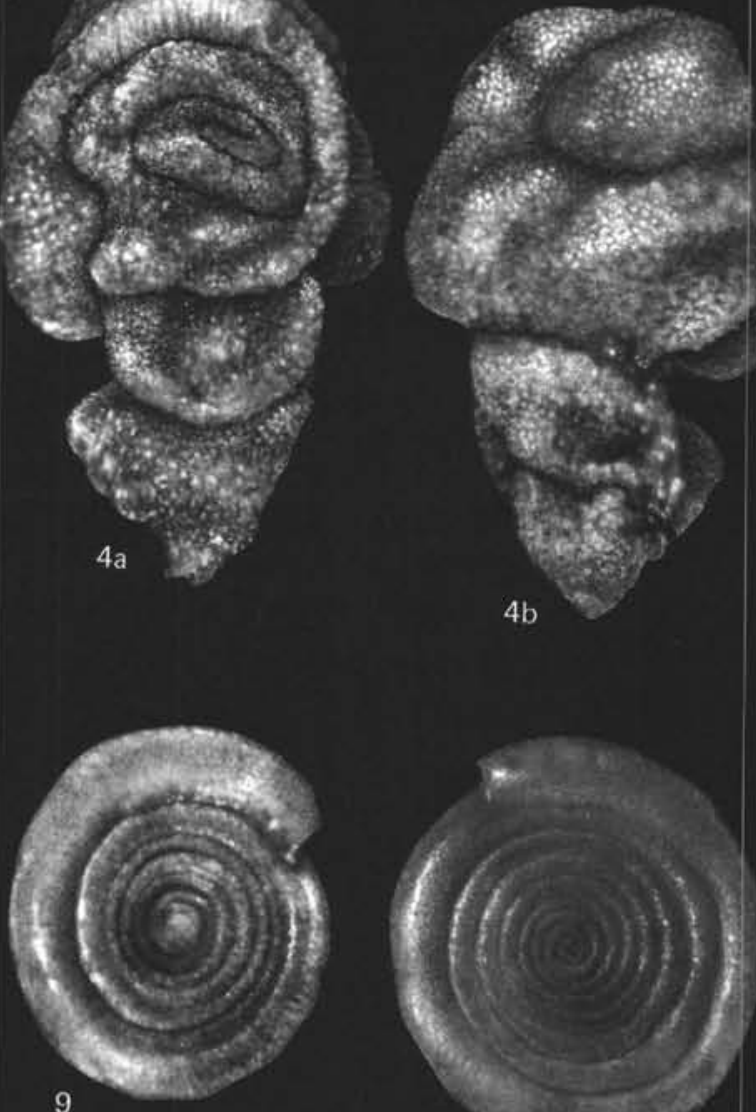

$4 b$ v
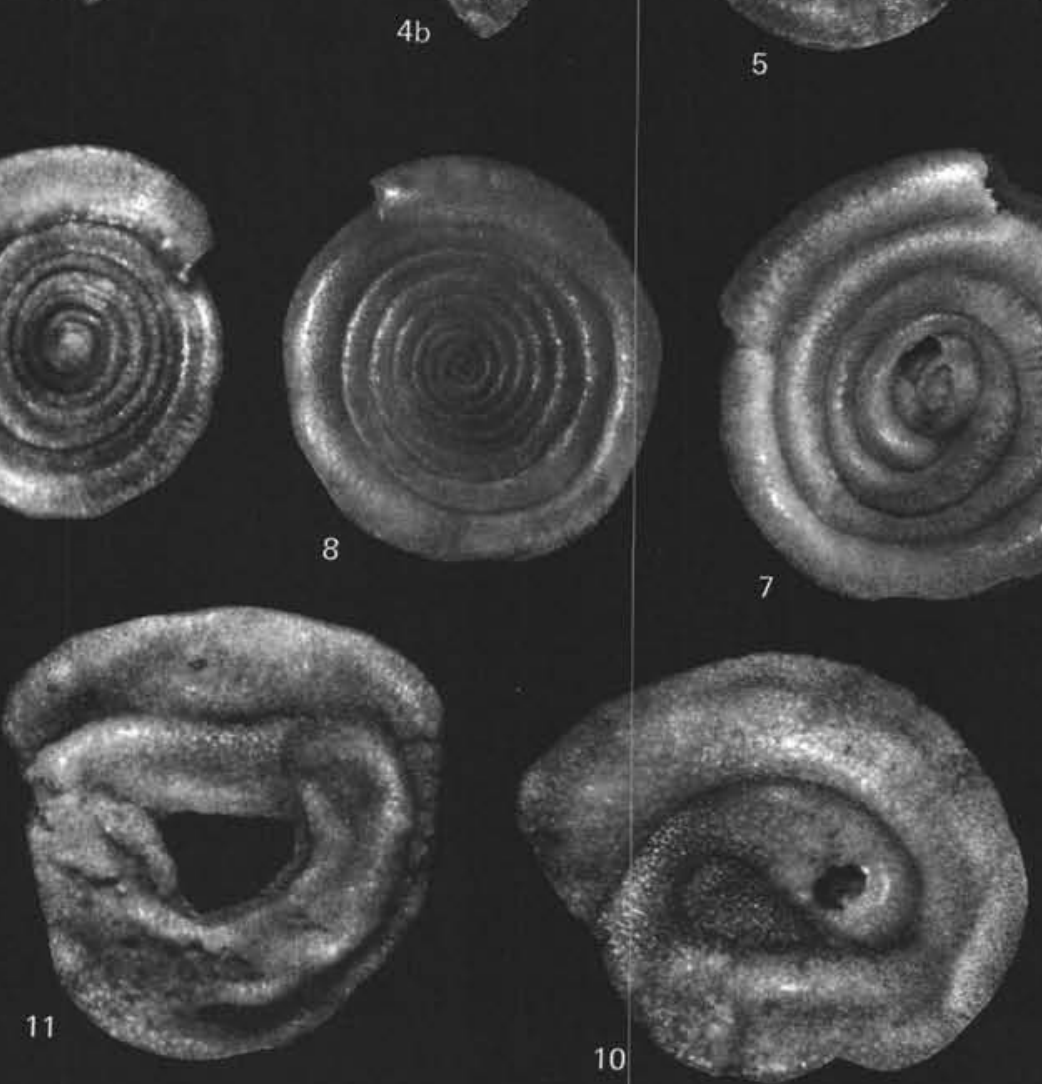

$12 \mathrm{a}$
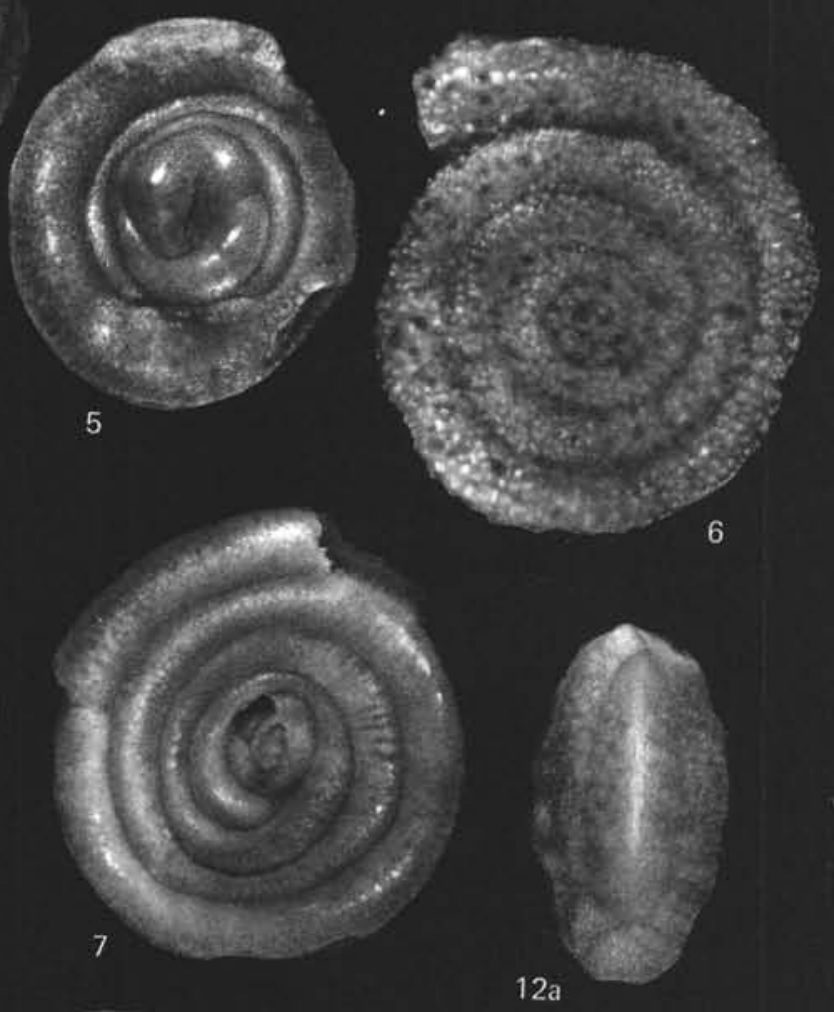


\section{PLATE 3}

Figures 1-3 Rzehakina epigona fissistomata (Grzybowski).

Sample 368-53, CC. $\times 75$, Upper Cretaceous.

Figures 4a, b Plectina conversa (Grzybowski).

Sample $368-58-3,73-75 \mathrm{~cm}, \times 75$, Upper Cretaceous.

Figures 5a, b, Rzehakina epigona epigona (Rzehak).

11 Sample 368-50, CC, $\times 75$, Upper Cretaceous.

Figures 6a, b Rzehakina epigona inclusa (Grzybowski).

Sample 368-50, CC, $\times 75$, Upper Cretaceous.

Figures 7, 8, 10 Spiroplectammina sp. sp.

7, 10. Sample 367-15 CC, $\times 75$, Upper Cretaceous.

8. Sample $370-24-3,73-75 \mathrm{~cm}, \times 100$, Lower Cretaceous.

Figure 9 Spiroplectammina gandolfi Carbonnier.

Sample $370-21-2,63-65 \mathrm{~cm}, \times 75$, Lower Cretaceous.

Figures 12a, b, Uvigerinammina jankoi Majzon.

13a, b 12. Sample 368-58, CC.

13. Sample 367-16, CC; $\times 100$, Upper Cretaceous.

Figures 14a, b Haplophragmoides $\mathrm{sp}$.

Sample $367-16$, CC, $\times 75$, Upper Cretaceous.

\section{PLATE 4}

Figures 1a, b, Dorothia oxycona (Reuss).

2a, b 1. Sample 367-15, CC, $\times 100$, Upper Cretaceous.

2. Sample 370-20-1, $43-45 \mathrm{~cm}, \times 75$, Lower Cretaceous.

Figures 3a, b Trochamminoides proteus (Karrer).

Sample 368-51, CC, $\times 50$, Upper Cretaceous.

Figures 4a, b Trochamminoides coronatus (Brady).

Sample 367-16, CC, $\times 75$, Upper Cretaceous.

Figures 5a, b, c Trochamminoides (?) sp.

Sample $367-15$, CC, $\times 75$, Upper Cretaceous.

Figures 6a, b, 7 Paratrochamminoides sp. sp.

367-15, CC. Upper Cretaceous.

6. $\times 50$.

7. $\times 75$.

Figures 8a,b,c Trochammina globigeriniformis altiformis Cushman and Renz.

Sample 370-26, CC, $\times 75$, Lower Cretaceous.

Figures 9a, b, c Recurvoides imperfectus Hanzlikova.

Sample 370-30, CC, $\times 75$, Lower Cretaceous. 
PLATE 3

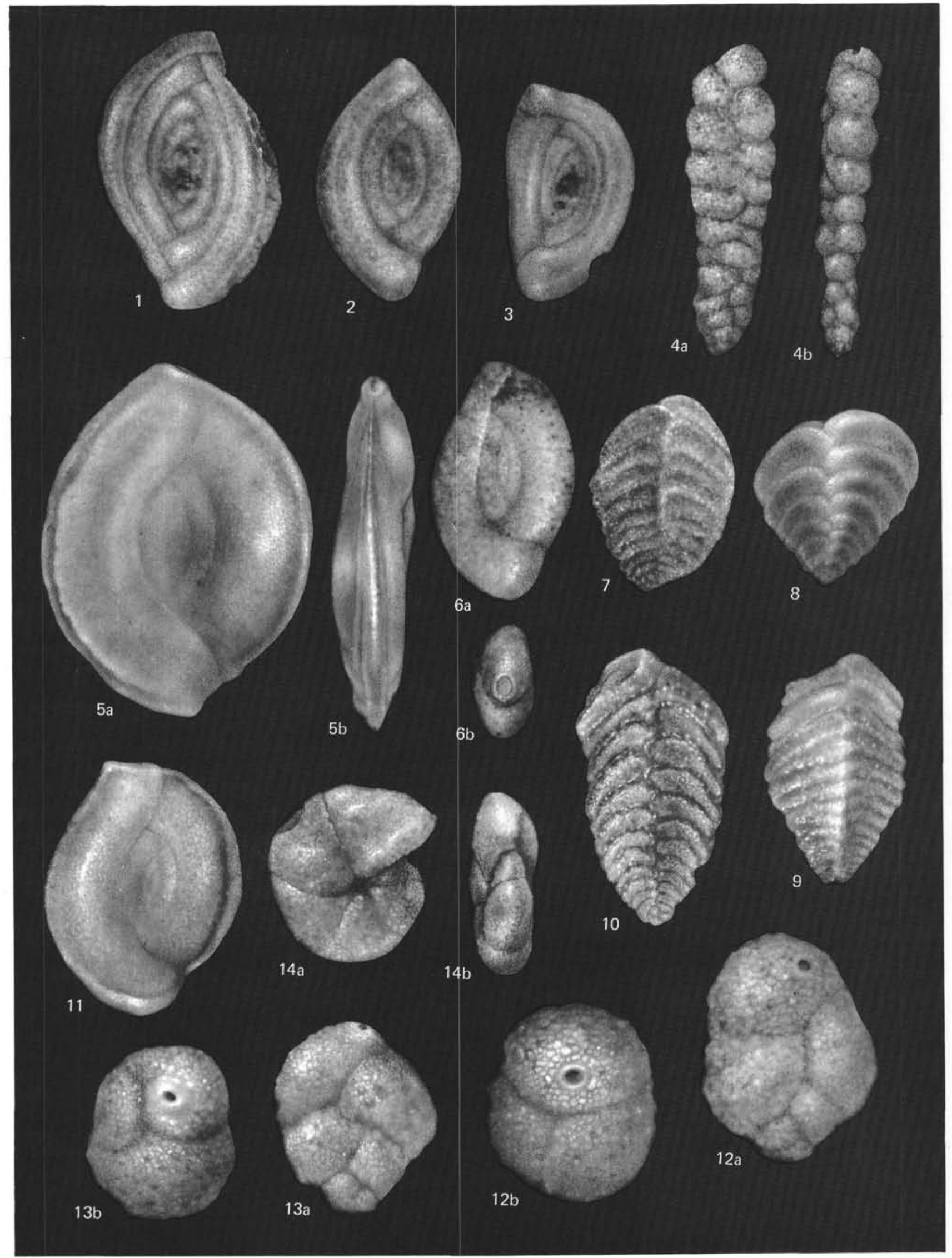




\section{PLATE 4}

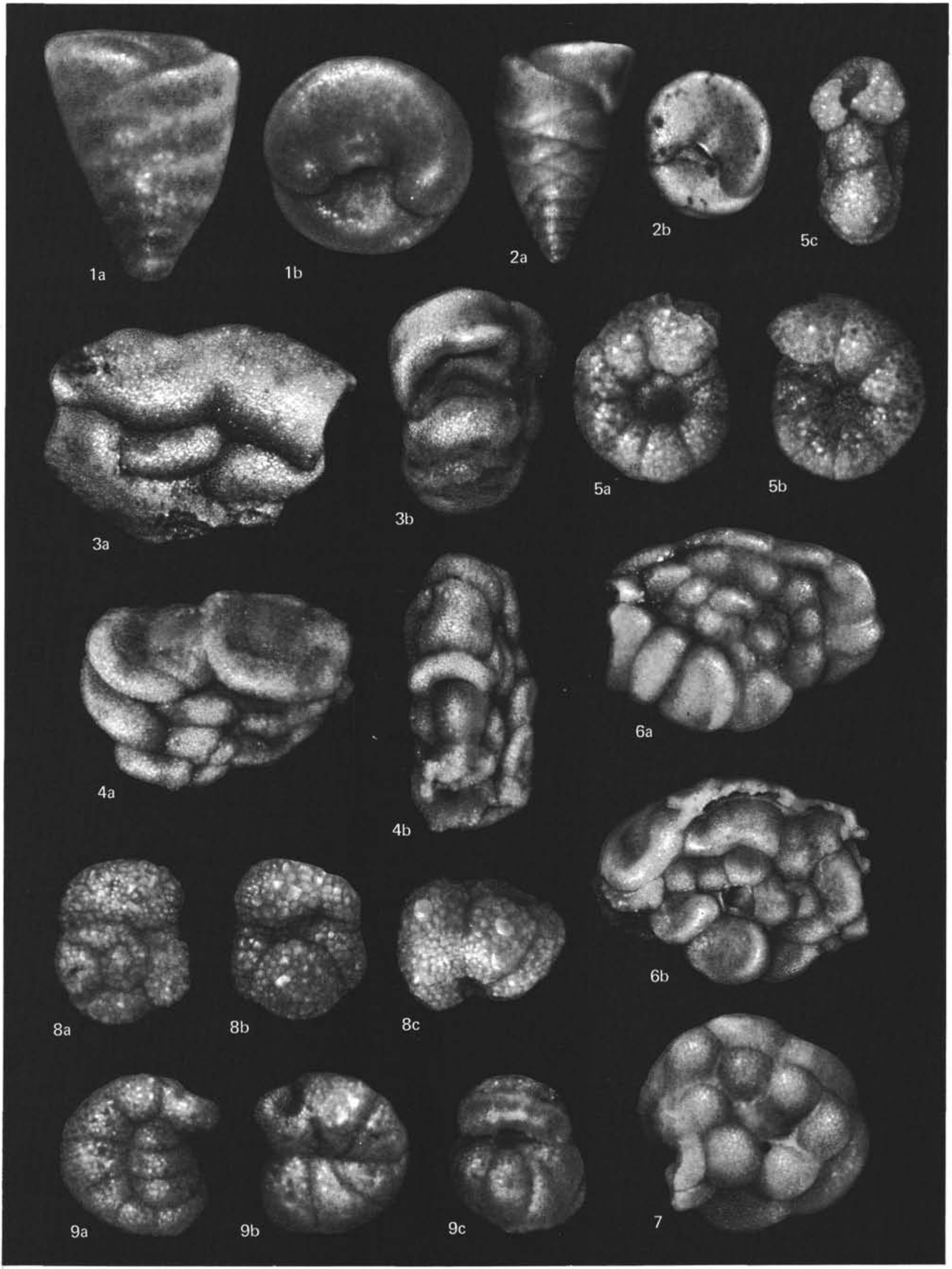




\section{PLATE 5}

Figures 1a, b, c Trochammina sp.

Sample 368-52, CC, $\times 50$, Upper Cretaceous.

Figures 2a, b, c Recurvoides gerochi Pflaumann.

Sample 368-52-3, 63-65 cm, $\times 75$, Upper

Cretaceous.

Figures 3a, b, c Recurvoides deflexiformis (Noth).

Sample 370-24-4, 73-75 cm, $\times 100$, Lower

Cretaceous.

Figures 4a,b, c Recurvoides aff, pseudosymmetricus Krasheninnikov.

Sample 370-25, CC, $\times 100$, Lower Cretaceous.

Figures 5a, b, c Thalmannammina cf. subturbinata (Grzybowski). Sample $368-52-5,78-80 \mathrm{~cm}, \times 75$, Upper Cretaceous.

Figures 6a, b, c Plectorecurvoides alternans Noth.

Sample 370-30, CC, $\times 75$, Lower Cretaceous.

Figures 7a, b, c Plectorecurvoides rotundus Krasheninnikov.

Sample 370-29, CC, $\times 100$, Lower Cretaceous.

(see page 580) 


\section{PLATE 5}

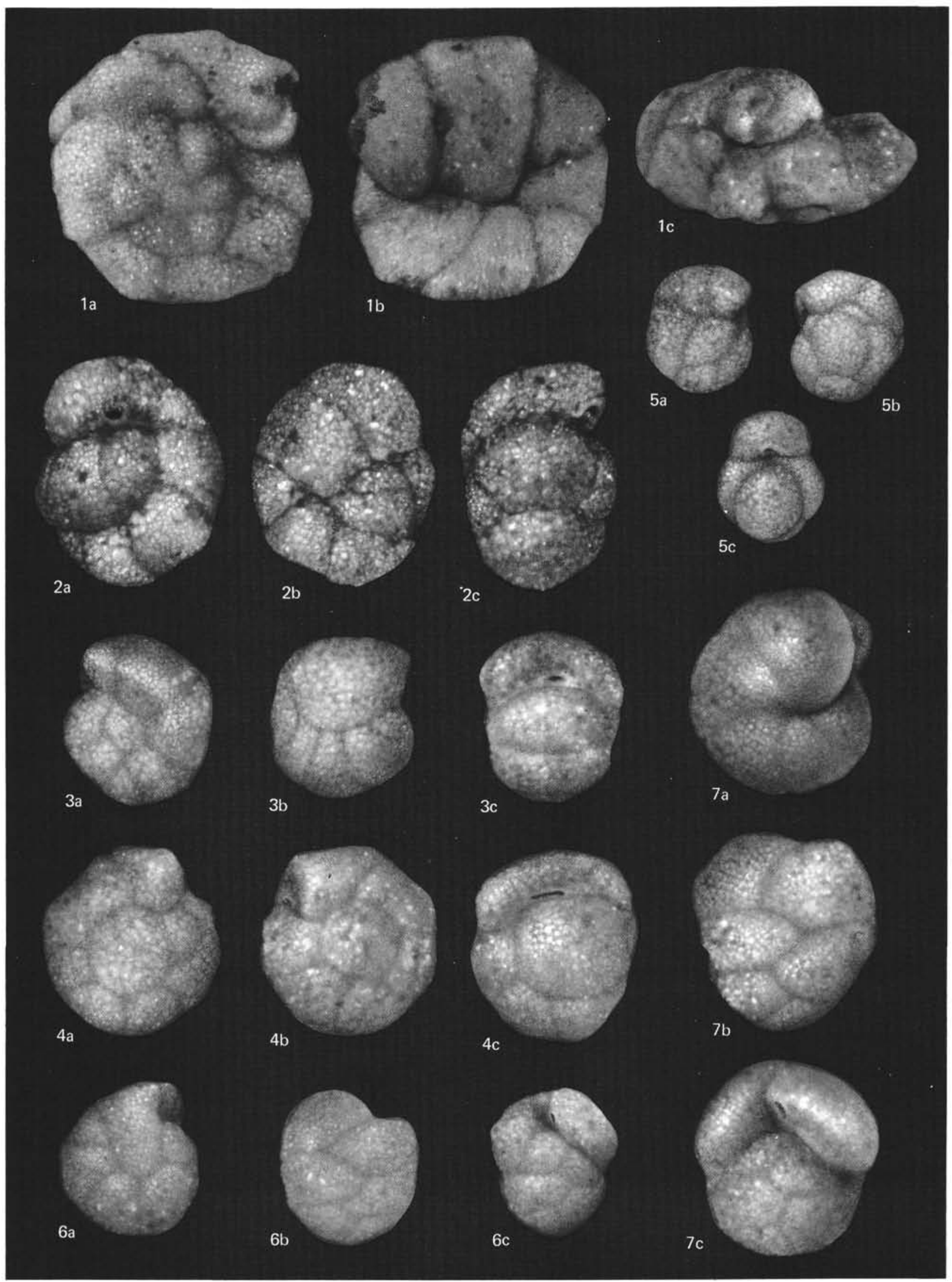

